\title{
Effects of Riverbed Extraction on Ground Water Resources in the Vicinity of Tinau River, Rupandehi
}

\author{
Khet R. Dahal ${ }^{1}$, Chandra P. Poudyal ${ }^{2}$, Prajwal Adhikari ${ }^{3}$, Subodh Sharma ${ }^{1}$ and Jitendra Ghimire ${ }^{4}$ \\ ${ }^{1}$ Department of Environmental Science and Engineering \\ Kathmandu University, Dhulikhel, Kavre \\ ${ }^{2}$ Department of Civil and Geomatics Engineering \\ Kathmandu University. Dhulikhel, Kavre \\ ${ }^{3}$ Nepal Earth Movers Pvt. Ltd, Butwal \\ Rupandehi \\ ${ }^{4}$ Nepal Hydro-geological Association \\ Kathmandu \\ e-mail: dahal.khetraj@gmail.com
}

\begin{abstract}
The study was carried out in the vicinity of the Tinau river, Rupandehi, Nepal from July 2011 to June 2012. Ten number of shallow tube wells (STWs) of depths $5.18 \mathrm{~m}$ to $7.62 \mathrm{~m}$, four shallow tube wells (STWs) of depths 28.96 $\mathrm{m}$ to $36.58 \mathrm{~m}$. from Amawa and Farsatikar Village Development Committees and one dug well (DW) from Butwal Municipality were selected for the purpose of this study. The depth of the STWs was different but many STWs were of $6.09 \mathrm{~m}$ deep. The DW was of $18.29 \mathrm{~m}$. The information was collected from the owners during field visit of the sites. A standard questionnaire was prepared and asked to the affected persons. The site observation was done in the dry season as well as in the rainy seasons. It was found that the extraction of riverbed materials from the river channel and the flood plain area has adversely affected the aquatic environment of the Tinau river. Massive extraction of the riverbed materials from this river started after the enforcement of local governance act, and regulation 1999. The income generated from the riverbed materials is quite enough. This is one of the major sources of income generation of DDC Rupandehi and the VDCs attached to this river (from Butwal to Bethari). The depth of the river increased due to extraction activities as a result groundwater table lowered. The STWs having depth of 5.18 to $7.62 \mathrm{~m}$ stopped discharging water from the aquifer in the dry season. Similarly DW of Butwal municipality having depth of $18.29 \mathrm{~m}$ stopped discharging water at dry season. But the STWs of depths from $28.96 \mathrm{~m}$ to 36.58 $\mathrm{m}$. located at the same area/site were not affected by the extraction in the Tinau river. The people, who are residing on the bank of the river Tinau, suffered from drinking water problem because they are using the water from STWs. The effect is directly facing the people of low and medium level having low income generation. The extraction activity is going on and the deficit of water availability in STWs and DW is common in the vicinity of the Tinau river especially in the upstream (from Butwal to Paschim Amawa), whereas there is less effects of riverbed extraction for STWs of depths more than $27.43 \mathrm{~m}$ in the same sites.
\end{abstract}

Key words: deep tube well, dug well, shallow tube well, Tinau river

\section{Introduction}

The river Tinau is a perennial river, originating from Mahabharat range of Palpa district, flowing from Madhi Phaant to the south of Nepal. It passes through the Terai plain from Butwal to Marchawar and joins the West Rapti river in India near Gorkhapur. Tinau is a groundwater fed river. The length of this River is about $95 \mathrm{~km}$ from Palpa (source) to the Indo- Nepal Border at Marchawar (Rupandehi), Nepal (Guragain 2012). But the width of this River varies from place to place. Generally the width is very less in upstream and it is greater in the downstream. Total catchment area 
of the Tinau Basin is 1081 sq.km. The basin area extends from $27^{0} 15^{\prime} \mathrm{N}$ to $27^{\circ} 45^{\prime} \mathrm{N}$ and $83^{\circ} 15^{\prime} \mathrm{E}$ to $83^{\circ} 45^{\prime}$ E.The main tributaries of Tinau are: Lakuri Khola, Pasdi Khola, Pugdi Khola, Budhare Khola, Sukhaura Khola, Rithe Khola, Bhobadi Khola, Sisne Khola, Khadal Khola, Hulandi Khola, Suridi Khola, Jhumsa Khola and Dhoban Khola (Guarani 2012;Kharel 2002). The river passes through the Bhabar Zone from the piedmont of Churia hills towards the south about $10 \mathrm{~km}$. The bhabar Zone consists of sand, cobble, pebble, boulder and bedrocks. This is the highly porous materials and thus can recharge the groundwater $r$ of this area and ultimately up to the Gangetic plain (Dixit \& Gyawali 1999).

The history of riverbed extraction is very old. It differs from country to country. But the history of riverbed extraction in Nepal for using the raw materials like sand and gravel started since 1963-1964 (Baidya 2003). The massive extraction in the Tianu was begun with the dawn of democracy. The Local Governance Act (1999) and Local Governance Regulation (1999) provided the right to local bodies to mobilize natural resources within the boundary of a VDC, DDC or municipality for their development. Thus the extraction of riverbeds to use raw material was expanded and the local bodies are keeping the record of riverbed extraction since then. The Tinau river was extracted massively since 2004 generating high incomes by the Village Development Committees (VDCs), municipalities and District Development Committee (DDC) (DWIDP 2011). The extraction has caused a lot of loss of aquatic lives. Thus, Tinau needs rehabilitation measures such as establishment of restricted areas for extraction of boulders, sand and aggregates from the river (DDC 2011).

In the Terai region of Nepal, the drinking sources of water are groundwater and mostly in irrigation too, groundwater plays a vital role. But the excessive use of groundwater may cause various problems related to environment. There is no strict rule and regulations for groundwater abstraction in Nepal. One can abstract groundwater from his own land but it may hamper the neighbor (Dulal \& Baral 2012). All most all people of the southern Terai of Rupandehi district use groundwater for drinking, irrigation, sanitation, livestock, industrial use, and so on. Abstraction of groundwater is usually done by means of shallow tube wells (STW), deep tube wells (DTW) and dug wells
(DW). Somewhere abstraction can be observed from the ponds too. Generally in the study area STW is constructed in shallow aquifer up to the depth from 6.09 to $7.62 \mathrm{~m}$ feet. The depth may be more based on the awareness, water availability in the aquifer, income, and the living standard of the people living in the area. Riverbed extraction invites various types of environmental effects and among them groundwater table lowering is one of the important one (Kondolf 1994). In the vicinity of the Tinau river, destruction of vegetative cover, river incision, breaching of bank, break down of the hydraulic structured can be observed. Similarly including dug well, many shallow tube wells (STWs) are dried due to less recharge (Scott et al. 1999), conducted a research on responses of riparian cottonwoods to water table declines. The research concluded that the extraction activities lower the alluvial water table in the vicinity of the extraction area.

About $20 \%$ of the world's fresh water comes from the groundwater (http://en.wikipedia.org/wiki/Groundwater). It is nearly $0.61 \%$ of the whole water of the world. It is roughly equal to the total amount of snow and ice deposited in any forms and in any part of the world. Excessive sand extraction from the riverbed and floodplain causes the depletion of groundwater table in the vicinity of the extracted areas. The extraction activity in the Tinau river is from Butwal to Bethari. The bhabar zone lies in this stretch of the river. And this zone of the river is also called the groundwater recharge zone (Dixit \& Gyawali 1999).

Most of the aquifers are recharged through the infiltration of rainfall in the bhabar zone in the Rupandehi district. The good quality of stones, sand and gravels are found in this region. Tinau is one of the important sources for sand and gravel. The total input to groundwater from the recharge is 464 Million Cubic Meter (MCM). Out of this, 201 MCM goes to the shallow aquifers and 263 MCM goes to the deep aquifers (Khatri et al. 2012).

The riverbed materials from the Tinau river is considered good for the construction works like buildings, roads, bridges, canal lining, and so on. There are number of crusher plants along the reach of the River. And the finished products from the crusher mills are being exported to India. The income from these materials is quite enough to raise the living standard 
of the industrialists and the revenue generated from these materials is being invested for socio- economic development of the district. But the standard manual/guidelines of extraction and constant monitoring mechanism from the concerned authority is lacking. The extraction activities are taking place haphazardly. Thus, there is a nuisance and degradation of aquatic environment in the Tinau river and it has negatively affected in many areas of the environment in and around the river but the scientific proof is to be searched.

\section{Methodology}

The study was carried out in Butwal Municipality, Paschim Amawa and Sauraha Farsatikar Village Development Committee (VDC) of Rupandehi district, Nepal. Ward number 4 of Paschim Amawa VDC, Ward no. 3 of Sauraha Farsatikar VDC and ward no. 13 of Butwal Municipality are selected for this study (The Fig. 1). The main objectives of the study are to assess the availability of groundwater in the villages/settlements located on the bank of the Tinau river; assessing the depletion of groundwater table and evaluating the impact of riverbed extraction on groundwater.

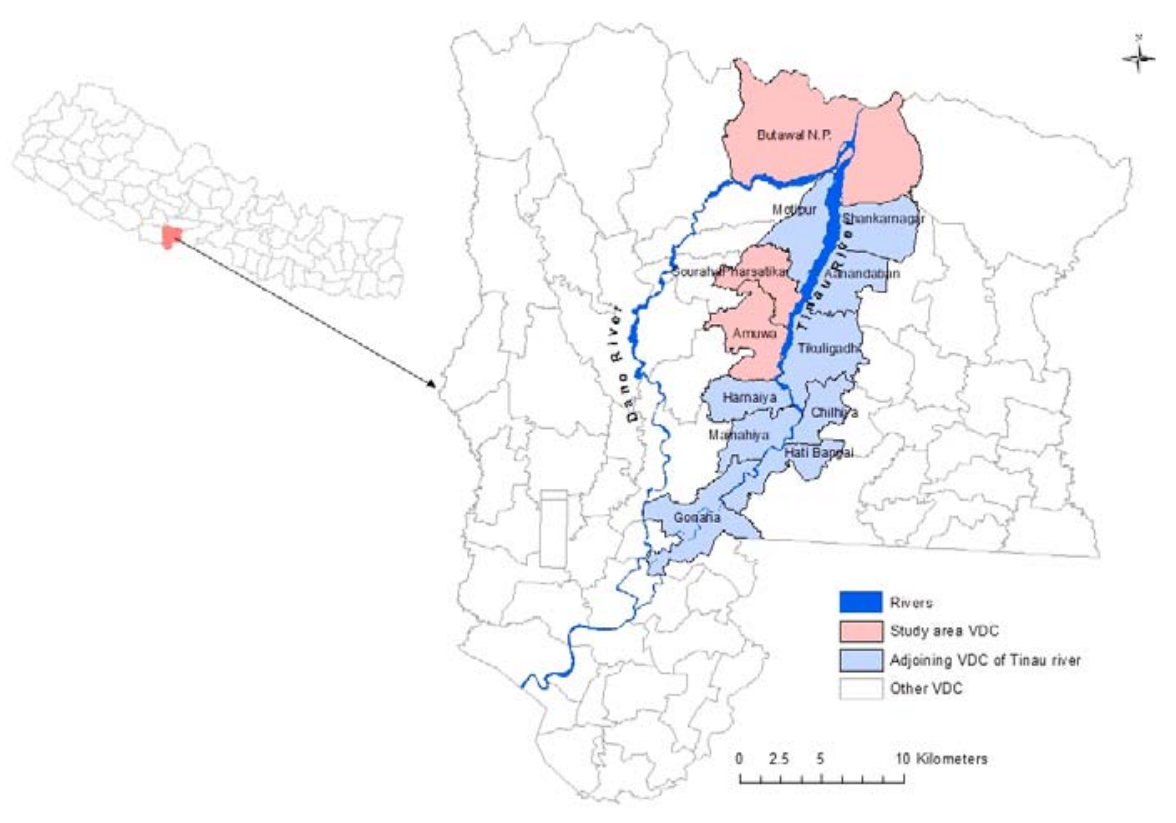

Fig. 1. Location map of study area

The site for this study was selected two VDCs, viz. Paschim Amawa and Sauraha Farsatikar and one Municipality (Butwal). Ward number 4 of Paschim Amawa VDC, Ward number 3 of Sauraha Farsatikar VDC and ward number 13 of Butwal Municipality were selected. 14 numbers (7 from each VDC) of STWs were selected for this study. Similarly one dug-well from Butwal Municipality was chosen. These tube wells and dug well are located on the bank of the Tinau river. The distance of dug well from the river channel is $251 \mathrm{~m}$ and tube wells
(STWs) are on average $309 \mathrm{~m}$. The distance was measured with the help of tape and elevation was measured using GPS. The research was conducted during the period of July 2011 to June 2012.

The site was so selected that the extraction activity was very massive from the location of the STWs, and DW. The site selection was made in accordance with the walk through survey along the river (Tinau). The locations of the wells are shown in figure 2 and derived using Geographic Information System (GIS). 


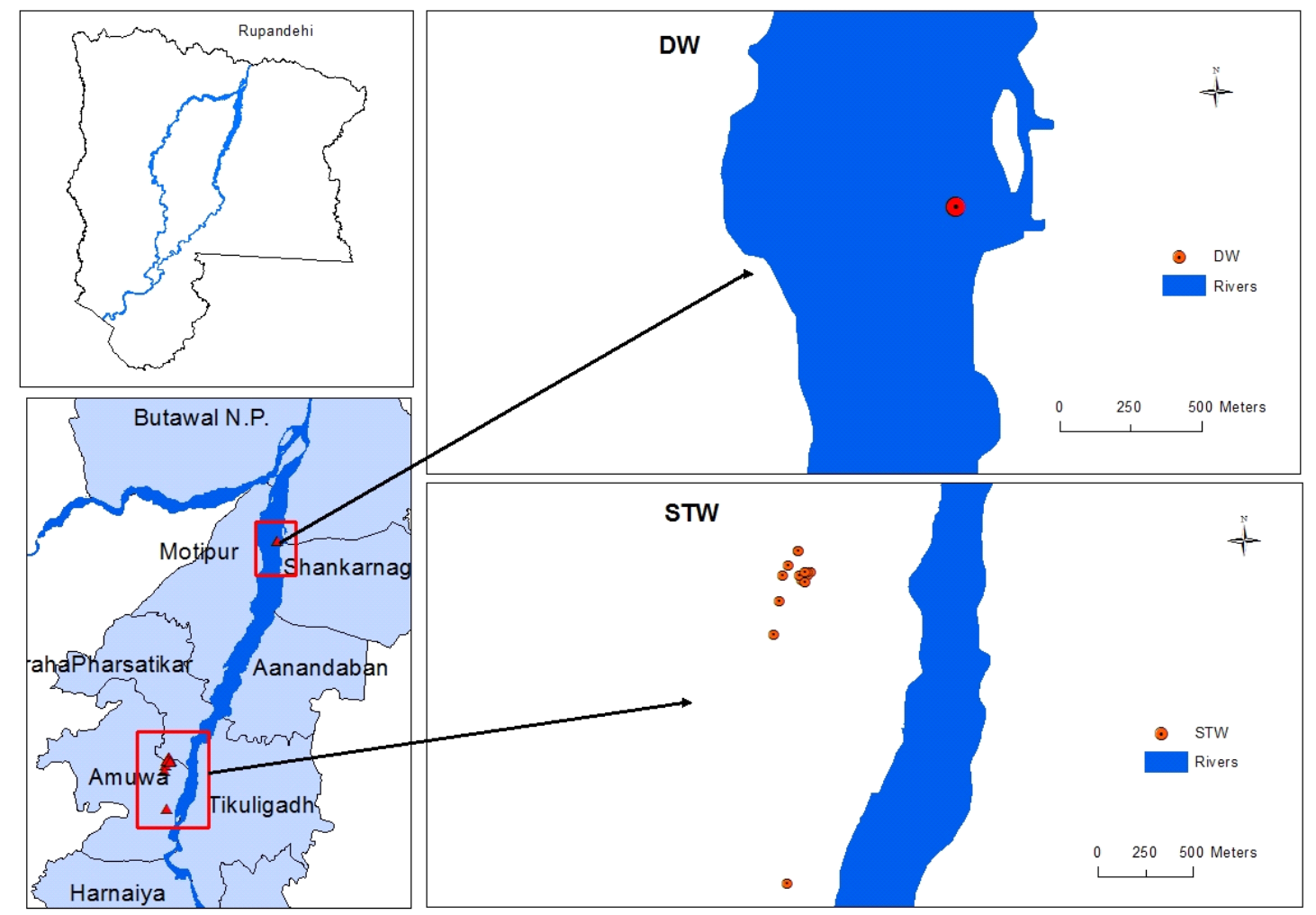

Fig. 2. Map showing location of STWs and DW in the study area

The situation of water availability in STWs was observed during the period of July to June 2011-2012. The observation was focused in the month of rainy and dry seasons for STWs and DWs. The water level fluctuation in dug-well was observed from July 2011, December 2011 and June 2012. The previous record of the dug-well was found from the owner. The comparison was made between past and present. The old and new level of riverbed was measured and calculated the level difference between past and present.

Except field observation, standard questionnaire were prepared and conducted a special social survey in the vicinity of the Tinau river. Eleven standard structured questionnaires were asked and the response of the respondents was included in the conclusion.

\section{Results and Discussion}

Shallow tube wells (STWs) of depths less than $7.62 \mathrm{~m}$.

The results of the observed shallow tube wells have shown that the riverbed extraction in the Tinau has adversely affected the aquatic environment. There is no water in the STWs during dry season (from April to June) in many cases in the vicinity of the Tinau river. The observed STWs all are dry (without water). The general characteristics of the observed STWs obtained from the field survey are given in the Table-1.

Table-1 provides the information about the observed STWs of Amana and Farsatikar VDCs of the Rupandehi District. The elevation of the STWs ranges from $95 \mathrm{~m}$ to $110 \mathrm{~m}$. and the distance of STWs from the bank of the Tinau river varies from $140 \mathrm{~m}$ to $400 \mathrm{~m}$.

During survey of the site $100 \%$ respondents claimed that the depletion of groundwater table is due to the riverbed extraction in the vicinity of the Tinau river. They reported that previously there was no massive extraction and water from the STWs discharged throughout the year. The excessive use of bulldozer and excavators (heavy equipment) caused degradation of the riverbed. And it caused the depletion of groundwater table of shallow aquifer in the vicinity of the Tinau river. 
Khet R. Dahal et al./Effects of Riverbed Extraction.

The elevation of the riverbed is lower than the elevation of the STWs (Field Survey). The average elevation of the riverbed is $96 \mathrm{~m}$. The average elevation of the STWs is $105 \mathrm{~m}$. The difference in elevation is
$105-96=9 \mathrm{~m}$. The average depth of the STW is $6.70 \mathrm{~m}$. and the depth of riverbed level is deeper than the depth of STW. Ultimately there is no recharge in dry season and the water in STWs do not appear.

Table1. Description of the observed shallow tube wells of depths less than $7.62 \mathrm{~m}$

\begin{tabular}{|c|c|c|c|c|c|c|c|c|c|c|c|}
\hline \multirow[b]{2}{*}{ STW } & \multirow[b]{2}{*}{ Location } & \multirow[b]{2}{*}{$\begin{array}{l}\text { Est. } \\
\text { Date }\end{array}$} & \multirow[b]{2}{*}{ Longitude } & \multirow[b]{2}{*}{ Latitude } & \multirow[b]{2}{*}{$\begin{array}{l}\text { Depth } \\
\text { (m) }\end{array}$} & \multirow[b]{2}{*}{$\begin{array}{l}\text { Pipe } \\
\text { Size } \\
(\mathrm{m})\end{array}$} & \multicolumn{2}{|c|}{ Water Level } & \multirow[b]{2}{*}{$\begin{array}{c}\text { Elev } \\
\text { ation } \\
(\mathrm{m})\end{array}$} & \multirow{2}{*}{$\begin{array}{l}\text { Distance } \\
\text { from STW } \\
\text { to River } \\
\text { channel } \\
\text { (m) }\end{array}$} & \multirow[b]{2}{*}{$\begin{array}{c}\text { Strainer } \\
\text { (m) }\end{array}$} \\
\hline & & & & & & & $\begin{array}{c}\text { Dry } \\
\text { Season } \\
(\mathrm{m})\end{array}$ & $\begin{array}{c}\text { Rainy } \\
\text { Season } \\
(\mathrm{m})\end{array}$ & & & \\
\hline 1 & Amuwa-4 & 2066 & $83^{0} 24.94^{\prime}$ & $27^{\circ} 35.86^{\prime}$ & 7.62 & 0.04 & 6.09 & 5.18 & 110 & 400 & 1.52 \\
\hline 2 & Amuwa-4 & 2057 & $83^{0} 25^{\prime}$ & $27^{\circ} 36^{\prime} .00$ & 6.40 & 0.04 & 5.94 & 4.87 & 107 & 385 & 0.91 \\
\hline 3 & Amuwa-4 & 2062 & $83^{\circ} 25^{\prime}$ & $27^{\circ} 36^{\prime} .00$ & 6.09 & 0.04 & 5.94 & 4.81 & 107 & 380 & 0.91 \\
\hline 4 & Amuwa-4 & 2060 & $83^{\circ} 25.04^{\prime}$ & $27^{\circ} 35.94^{\prime}$ & 6.09 & 0.04 & 5.91 & 4.72 & 108 & 300 & 0.91 \\
\hline 5 & Amuwa-4 & 2056 & $83^{\circ} 25.01^{\prime}$ & $27^{\circ} 35.92^{\prime}$ & 6.40 & 0.04 & 5.79 & 4.74 & 108 & 320 & 0.91 \\
\hline 6 & Farsatikar-3 & 2052 & $83^{\circ} 25.029^{\prime}$ & $27^{\circ} 35.93^{\prime}$ & 5.79 & 0.04 & 5.78 & 4.67 & 106 & 140 & 0.91 \\
\hline 7 & Farsatikar-3 & 2066 & $83^{\circ} 25.03^{\prime}$ & $27^{\circ} 35.94^{\prime}$ & 6.09 & 0.04 & 5.79 & 4.57 & 106 & 160 & 0.91 \\
\hline 8 & Farsatikar-3 & 2044 & $83^{\circ} 25.004^{\prime}$ & $27^{\circ} 35.93^{\prime}$ & 6.09 & 0.04 & 5.48 & 4.51 & 100 & 400 & 0.91 \\
\hline 9 & Farsatikar-3 & 2060 & $83^{\circ} 24.97^{\prime}$ & $27^{\circ} 35.05^{\prime}$ & 4.87 & 0.04 & 4.57 & 4.42 & 95 & 200 & 0.06 \\
\hline 10 & Farsatikar-3 & 2063 & $83^{\circ} 24.97^{\prime}$ & $27^{\circ} 35.96^{\prime}$ & 6.09 & 0.04 & 5.64 & 4.7 & 100 & 400 & 0.06 \\
\hline
\end{tabular}

Source: Field Survey, 2011-2012

Shallow aquifers are those aquifers which can be reached by means of STWs or DWs. These aquifers are recharged through the precipitation. Rivers with porous materials and located at high elevation than the STWs or DWs also recharge these aquifers (htpp:// www.infonet-biovision.org/default/ct/282/ soilConservation). This justifies the drawdown of the aquifer in the periphery of the Tinau river. The river deepened and the shallow aquifers located at the vicinity of the River that were recharged through the porous materials of the riverbed, were adversely affected. The recharge from the river to the adjoining shallow aquifers was became failure. Thus, the water table in the shallow DWs and STWs depleted and those sources of water supply became obsolete.

Generally STWs are inserted up to shallow aquifer. The aquifers in the Rupandehi district recharges through Bhabar zone. It affects specially in the vicinity of the Tinau river (Gurung, et al. 2012). The riverbed materials are found in this section (bhabar zone) of the Tinau river, where massive extraction took place during the past years. The extraction activity adversely affects the groundwater recharge of this area (Dixit \& Gyawali 1999). Tinau is a influent river and the river recharges not only the vicinity or adjoining areas of Rupandehi district but also the part of the Gangetic plain (Butwal Municipality 2001). Now the area is converting into the city of cement concrete due to over population, industrialization and urbanizations. The agricultural land is converting into either road or building houses. These are also the obstacles for recharging groundwater.

\section{Shallow tube wells of depths more than $7.62 \mathrm{~m}$}

The result showed that the shallow tube wells (depth more than $27.43 \mathrm{~m}$ ) have no effects of riverbed extraction. The observed STWs and their characteristics are given in the Table 2.

The above Table 2 shows that the elevation of the STWs varies from $105 \mathrm{~m}$ to $115 \mathrm{~m}$. The distance of STWs from the bank of the river is $150 \mathrm{~m}$ to $400 \mathrm{~m}$. The depth of the wells ranges from $4.87 \mathrm{~m}$ to $120 \mathrm{~m}$. There are no visible effects of gravel extraction on STWS of depths more than $27.43 \mathrm{~m}$. All these STWs are in deeper than the riverbed level. Thus, there are no effects of riverbed extraction. 
Nepal Journal of Science and Technology Vol. 13, No. 2 (2012) 133-140

Table 2. Characteristics of observed STWs of depths more than $7.62 \mathrm{~m}$

\begin{tabular}{|c|c|c|c|c|c|c|c|c|c|c|c|}
\hline \multirow[b]{2}{*}{ STW } & \multirow[b]{2}{*}{ Location } & \multirow[b]{2}{*}{$\begin{array}{l}\text { Est. } \\
\text { date }\end{array}$} & \multirow[b]{2}{*}{ Longitude } & \multirow[b]{2}{*}{ Latitude } & \multirow[b]{2}{*}{$\begin{array}{l}\text { Depth } \\
\text { (m) }\end{array}$} & \multirow[b]{2}{*}{$\begin{array}{l}\text { Size } \\
(\mathrm{m})\end{array}$} & \multicolumn{2}{|c|}{ Water Level (m) } & \multirow[b]{2}{*}{$\begin{array}{l}\text { Eleva } \\
\text { tion } \\
(\mathrm{m})\end{array}$} & \multirow{2}{*}{$\begin{array}{l}\text { Distance } \\
\text { from } \\
\text { STW to } \\
\text { river } \\
\text { channel, } \\
\text { (m) }\end{array}$} & \multirow[b]{2}{*}{$\begin{array}{l}\text { Strainer } \\
\text { (m) }\end{array}$} \\
\hline & & & & & & & Dry & Rainy & & & \\
\hline 1 & Amuwa-4 & 2065 & $83^{\circ} 24.92^{\prime}$ & $27^{\circ} 35.76^{\prime}$ & 27.43 & 0.04 & 4.27 & 2.71 & 115 & 400 & 0.60 \\
\hline 2 & Amuwa-4 & 2062 & $83^{\circ} 24.95^{\prime}$ & $27^{\circ} 35.93^{\prime}$ & 36.58 & 0.04 & 4.20 & 2.59 & 106 & 490 & 0.60 \\
\hline 3 & Farsatikar-3 & 2064 & $83^{\circ} 25.02^{\prime}$ & $27^{\circ} 35.94^{\prime}$ & 36.58 & 0.04 & 4.23 & 2.65 & 105 & 150 & 0.60 \\
\hline 4 & Farsatikar-3 & 2061 & $83^{\circ} 25.02$ & $27^{\circ} 35.91^{\prime}$ & 28.96 & 0.04 & 4.25 & 2.62 & 107 & 200 & 0.60 \\
\hline
\end{tabular}

Source: Field Survey, 2011-2012

There are some deep tube wells (DTWs) in the Rupandehi district. Water in the Deep Tube Wells (DTWs) is generally from the deep aquifers. The water in the deep aquifers is collected by deep percolation. It takes centuries or thousands of years for water collection in the deep aquifers. Thus these aquifers are not affected by the riverbed extraction. The DTWs can be affected by the over abstraction of groundwater (Khatri et al. 2012 and htpp://www.infonetbiovision.org/default/ct/282/soilConservation).

\section{Dug well}

The selected dug well is located at Butwal-13, Rupandehi, within the ground of the Nepal Earth Movers (NEM) Pvt. Ltd. NEM is one of the biggest crusher industries of the Rupandehi district. The history of this dug well is of nearly ten years backing. It was constructed in May 2002. At that time, the depth of this well was only $10.98 \mathrm{~m}$. It was continued to discharge the sufficient quantity of water for only one year. Then the well dried (NEM 2011). Thus the company needed to deepen the existing dog well. Nepal
Earth Movers Pvt. Ltd. reconstructed the dug-well and reached up to the depth of $18.29 \mathrm{~m}$. Then the observed dug well started functioning well. The general sketch of the dug well is given in Fig. 3.

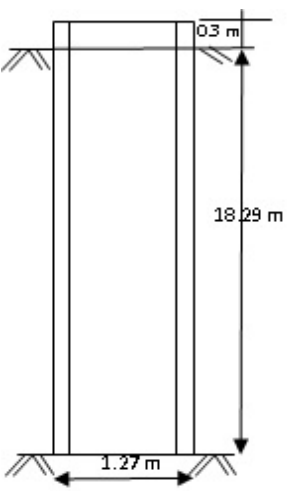

Fig. 3. Sketch of the dug well (not in scale)

The company maintained the records of the well from 2004 to 2010. The previous records of the dug-well are given in the table 3 .

Table 3. Previous records of the dug well (DW)

\begin{tabular}{l|c|l}
\hline Observed date & Total depth, $\mathrm{m}$ & $\begin{array}{l}\text { Observed water level, } \mathrm{m} \\
\text { (From the top GL to water level of dug- well) }\end{array}$ \\
\hline $2005 / 5 / 30$ & 18.29 & 16.00 \\
$2005 / 7 / 10$ & 18.29 & 2.13 \\
$2006 / 5 / 30$ & 18.29 & 16.92 \\
$2006 / 7 / 10$ & 18.29 & 2.74 \\
$2007 / 5 / 30$ & 18.29 & 17.37 \\
$2007 / 7 / 10$ & 18.29 & 3.50 \\
$2008 / 5 / 30$ & 18.29 & 17.83 \\
$2008 / 7 / 10$ & 18.29 & 3.81 \\
$2009 / 5 / 30$ & 18.29 & No water \\
$2009 / 7 / 10$ & 18.29 & 3.81 \\
$2010 / 5 / 30$ & 18.29 & No water \\
\hline
\end{tabular}

Source: Nepal Earth Movers Pvt. Ltd., 2011 
The table shows that the fluctuations of the water level in the dug well started from the very beginning. But there was sufficient water in the rainy season. The water level was very low in the year 2008 and there was no water in the dry season in the year 2009 and 2010. During this period there was massive extraction and the river was already deepened (NEM 2011).

\section{Analysis of rainfall}

The rainfall record of the study area was obtained from the department of hydro-meteorology, Babarmahal, Kathmandu. Butwal is one we had taken because of the recharge zone for the groundwater in the study area. The status of rainfall of the Butwal station is shown in the fig. 4.

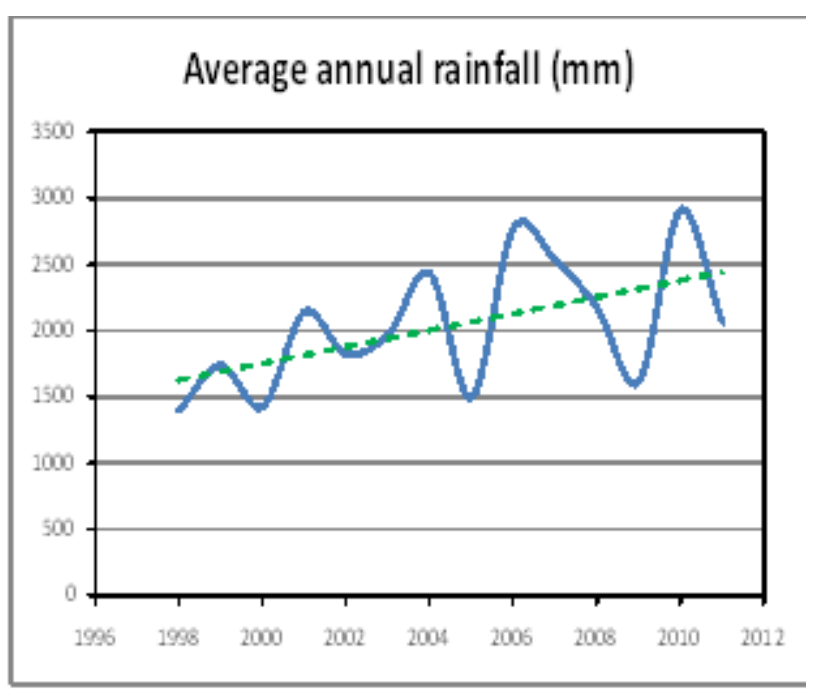

Fig. 4. Average annual rainfall of Butwal area (1998-2011)
The Butwal area precipitation rate is slightly increases and the increase in precipitation increases in the groundwater recharge. But in actual scenario there are some of the wells are shown to be lower water level (Table 3). On the other hand table three shows that there are level increases only at the rainy season and after two months the water level decreases significantly or sometimes there is no water. This is due to the situation that during the rainy season the groundwater was feed by the river to the shallow area and after stopping the rain the river will feed by the shallow water. As the river bed extraction increases the water table is above the river bed and due to gravity the water from underground flows towards river. The recharge of groundwater during monsoon will increases the water table in wells, where as the river feeding by groundwater influences the table other than rainy season. The research was further continued for the investigation of the dug well. The general characteristics of the dug well during study period are given in the table 4. Again there was a great fluctuation of water level. In the dry season there is no water in the well (especially from the month of May it dried completely and again water appears in the rainy season). There could be seen water level in the dry season too, when the bed-level of dug-well was deeper than the riverbed level (NEM 2011).

The elevation of the dug-well is $145 \mathrm{~m}$ and the elevation of the riverbed level is $126 \mathrm{~m}$. The difference in elevation is $19 \mathrm{~m}(62.32 \mathrm{ft})$. The depth of the dugwell is only $18.29 \mathrm{~m}$. The riverbed is $0.70 \mathrm{~m}$ deeper than the depth of the well. Thus it is clear that the extraction has caused the depletion of groundwater table in the observation dug-well.

Table 4. General characteristics of the observed dug-well during study period (2011-2012)

\begin{tabular}{l|c|c|c|cc|c}
\hline Coserved Date & Longitude & Latitude & $\begin{array}{c}\text { Elevation } \\
(\mathrm{m})\end{array}$ & $\begin{array}{c}\text { Total } \\
\text { Depth (m) }\end{array}$ & $\begin{array}{c}\text { Observed Water } \\
\text { Level from the } \\
\text { top of the well } \\
(\mathrm{m})\end{array}$ & $\begin{array}{c}\text { Distance of DW } \\
\text { from river channel } \\
\text { (m) }\end{array}$ \\
\hline $2011 / 07 / 15$ & $83^{\circ} 27.24^{\prime}$ & $27^{\circ} 40.02^{\prime}$ & 145 & $\mathbf{1 8 . 2 9}$ & 4.57 & 251 \\
$2011 / 12 / 15$ & $83^{\circ} 27.24^{\prime}$ & $27^{\circ} 40.02^{\prime}$ & 145 & $\mathbf{1 8 . 2 9}$ & 9.75 & 251 \\
$2012 / 06 / 15$ & $83^{\circ} 27.24^{\prime}$ & $27^{\circ} 40.02^{\prime}$ & 145 & $\mathbf{1 8 . 2 9}$ & No water & 251 \\
\hline
\end{tabular}

source: rieiu survey, $\angle U \perp \perp-\angle U \perp \angle$

Walawa river in Srilanka was degraded due to riverbed extraction and a research was carried out in August 2010. It was found that the water table in dug-well was lowered by $11 \mathrm{~m}$ during a period of 10 years. The location of the dug-well was very near to the river bank. The research concluded that the extraction activity lowers the bed level of the river and simultaneously it lowers the water table (level) of dug well located at the vicinity of the River (Impact of River Sand Mining 2010). The case of Tinau is similar to 
Walawa river in Srilanka. So the depletion of groundwater table of the observation dug-well is due to the extraction of riverbed materials.

Bhabar zone of Nepal recharges the groundwater of Terai belt. The recharge process extends up to the Gangetic plain. The rivers flowing through this zone disappear at some points of Bhabar zone and reappears after the end of the Bhabar zone. The river Tinau has such characteristics. The riverbed materials in the Tinau river are composed of sand, cobble, pebble, boulder, bedrock, and so on. All these materials are porous materials and easily transfers surface water into the groundwater. In this way, the recharge process of this area continues. Thus, the STWs, and DWs located at the bank of the river, are getting water in shallow depths. The recharge rate decreases as the river flows down of the Bhabar zone.

Most of the riverbed materials are found in the Bhabar zone. These construction materials are extensively extracting by the different agencies from the last ten years. And the river is deepening. There are various effects of riverbed extraction on the aquatic environment, but one of the indicative effects is groundwater depletion located at shallow aquifers. The average level difference of shallow tube well to riverbed is $9 \mathrm{~m}$. The average depth of the shallow tube wells is 6.09 to $7.62 \mathrm{~m}$. The river deepened more than the depth of the shallow tube well. Thus, there is no recharge of the groundwater from the Tinau river for shallow tube wells and dug wells located at the bank of the river during dry seasons in the past. Thus, the STWs and DWs are failed to yield the discharge. Therefore the river must be conserved for improving aquatic environment.

\section{Acknowledgements}

Mr. Mahesh Pathak helped us for preparation of map in GIS. Mr. Yagya Raj Adhikari provided us information related to the observation dug-well located inside his crusher plant. We are grateful to them and would like to acknowledge.

\section{References}

Baidya, H.R. 2003. Twelve years struggle for the conservation of Bagmati River. Nepal Water Conservation Foundation, Kathmandu.
DDC. 2011. Environmental Impact Assessment of Tinau, Dano, Rohini and Kanchan Rivers. Draft Report. District Development Committee, Rupandehi, Nepal.

Dixit, A. and D. Gyawali. 1999. Fractured institutions and physical interdependence, challenges to local water management in the Tinau River Basin, Nepal, Nepal Water Conservation Foundation. pp. 58.

Dulal, K.N. and S. Baral. 2012. Soil Erosion. In: Engineering Hydrology. APEX Educational Academy, Kathmandu.

ERMC Pvt. Ltd. 2011. Detailed Feasibility Study for Tinau Integrated Development Project. Department of Water Induced Disaster Prevention (WIDP).

Government of Nepal. 1999. Local Governance Act. Ministry of Law, Justice and Parliamentary Affairs.

Government of Nepal.1999. Local Governance Regulations. Ministry of Law, Justice and Parliamentary Affairs.

Guragain, H. 2012. Impacts on Hydraulic Structure due to Riverbed Extraction. M.Sc.Thesis. Lumbini Engineering College, Pokhara University, Nepal.

Gurung, C.B., S. Shrestha, S. Shah and S.R. Shrestha. 2012. Status of shallow tubewell irrigation and shallow aquifer in Rupandehi district. In: Unpublished paper presented in Ground Water Resources:Effects and Utilization, seminar, 24 March.

Kharel, L.N. 2002. Description of the Tinau River. Institute of Engineering, Pulchowk Campus, Tribhuvan University, Nepal.

Khatri, N., B.B. Khatri and D.R. Thapa. 2012. Lithological settings of Bhairahawa Lumbini Groundwater Irrigation Project. Unpublished paper. National seminar on 24 March. Butwal, Nepal.

Kondolf, G.M. 1994. Environmental Planning in Regulation and Management of Instream Gravel Mining in California. Landscape and Urban planning 29: 185-199

Nepal Earth Movers (NEM). 2011. Unpublished official records of dug-well.

Nepal Engineers' Association, Lumbini Regional Centre, Butwal. 2001. Save the Tinau. Butwal Municipality.

Scott, M.L., B. Patrik, F. Shah and T.A. Greeger. 1999. Responses of riparian cottonwoods to alluvial water table declines. Environmental Management 23(3):347-358.

Volunteer team of net water, Srilanka. 2010. Impact of River Sand Mining, in Ratanpura District in Sabaragamuwa Province. Concise Report.

http://en.wikipedia.org/wiki/Groundwater, accessed in 15

June, 2012.

htpp://www.infonet-biovision.org/default/ct/282/ soilConservation, accessed in 3 March, 2012. 